\title{
Patiëntenvoorlichting
}

\section{PV 29 Erythema multiforme}

Erythema multiforme is een ontstekingsachtige, niet besmettelijke aandoening van de huid en/of slijmvliezen. Erythema betekent roodheid, terwijl multiforme betrekking heeft op de veelvormigheid waarin deze ziekte zich kan voordoen. Het betreft vooral kinderen en jongvolwassenen. Als oorzaak wordt onder andere gedacht aan een reactie op geneesmiddelen, bij voorbeeld penicilline. Daarnaast lijkt de afwijking te kunnen veroorzaakt door een herpesvirus. In veel gevallen is de oorzaak niet echt te achterhalen. De ziekte kan in de mond beginnen en pas later ook slijmvliezen op andere plaatsen, bij voorbeeld van het oog of de uitwendige geslachtsorganen, of de huid aandoen. Soms blijft erythema multiforme beperkt tot de mond en de lippen. De mondafwijkingen bestaan meestal uit meerdere oppervlakkige, pijnlijke zweren. De ziekte gaat met koorts en algehele malaise gepaard. De diagnose kan meestal worden gesteld op grond van de verschijningsvorm en de algemene ziekteverschijnselen. Toch wordt vaak een weefselstukje van het aangedane slijmvlies of de huid afgenomen voor onderzoek door de patholoog.

In principe gaat erythema multiforme binnen 2-6 weken weer vanzelf over. Er zijn geen medicijnen om deze genezingsduur daadwerkelijk te bekorten. Soms komt de ziekte na enige tijd weer terug.

\section{Wat kunt u zelf doen?}

U kunt bij het vermoeden op aanwezigheid van erythema multiforme zelf niets doen. Het is belangrijk om ondanks de pijnlijke mond voldoende vocht in te nemen en te proberen de mond zo goed mogelijk schoon te houden, desgewenst met behulp van een mondspoeling.
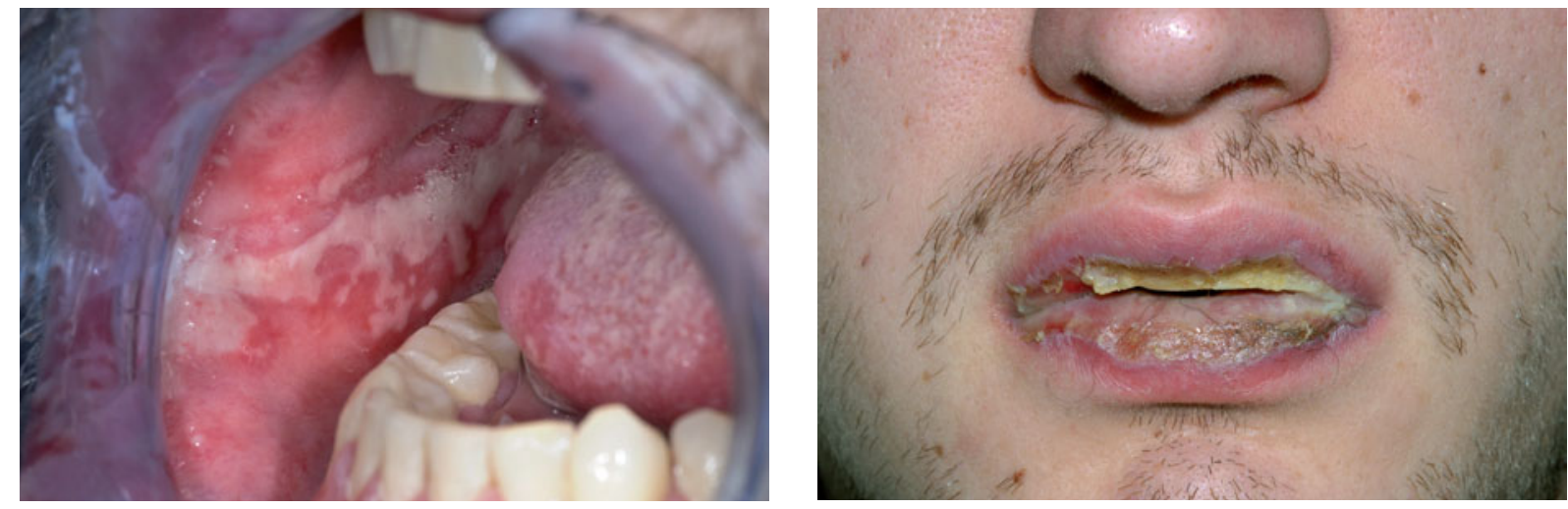